\title{
Nuclear forms of superoxide dismutase, catalase and peroxidase
}

\author{
Alexander F. Protas \\ Research Centre for Radiation Medicine \\ 53 Melnikova str., Kiev 254050, Ukraine
}

\begin{abstract}
Nuclei f rat brain cortex cells contain own specific forms of superoxide dismutase ( $S O D)$, catalase (CAT) and gluthatione peroxidase $(G P X)$. The enzymes are firmly associated with chromatin, preferationally with transcriptionally active fraction and released from nuclei completely with $>1.2 \mathrm{M} \mathrm{NaCl}$. $M_{\mathrm{r}}$ of SOD is $10 \mathrm{kDa}, \mathrm{CAT}$ and $\mathrm{GPX} 44 \mathrm{kDa}$ (gelfiltration). Isoelectric points of $S O D$ is under pH 6.0, CAT and GPX 5.8 (chromatofocusing). The activities of enzymes depend on ionic strength and are maximal under $>1.1 \mathrm{M} \mathrm{NaCl}$. Nuclear SOD are not inhibited with KCN and thus, it is MnSOD.
\end{abstract}

Introduction. It is well-known that under the normal metabolic pathways molecular oxygen forms several types of primary and secondary free radicals and a large number of non-radical products, which are sucseptible to interact with any cellular macromolecules and inducing alteration of cellular function. Approximately $1-5 \%$ of normal cellular oxygen metabolism yields potentially reactive free radicals [1]. Nuclei can produce up to $25 \%$ of total cell $\mathrm{O}_{2}$ [2]. Nuclei contain near the same quantity of total superoxide dismutase (SOD), catalase (CAT) and gluthatione peroxidase (GPx) [3].

It is generaly accepted that cells contain two types of SOD: $\mathrm{Cu}, \mathrm{ZnSOD}$ cytoplasmic and MnSOD mitochondrial. The data about of nuclear SOD are not clear still. Some authors consider, that nuclei do not contain own SOD and uses cytoplasmic $\mathrm{Cu}, \mathrm{ZnSOD}$ [2]. In developing brain cells about half of nuclear SOD is not inhibited with $\mathrm{KCN}$. It means that nuclei can contains the both $\mathrm{Cu}$, $\mathrm{ZnSOD}$ and MnSOD types [3]. The studies on fish erythrocytes, which has nuclei and no mitochondria, had suggested that nuclei contains only MnSOD [4]. The information about the nature of nuclear CAT and GPx is much more poor. In spite of a greate importance to protect DNA against free radicals these problem is not discussed.

Materials and Methods. Adult Wistar rats were used. Nuclei from cerebral cortices were isolated in sucrose media including treatment with Triton $X-100$ [4]. SOD activity was assayed with the method of adrenaline autooxidation [5] with a slight modification: wavelength $340 \mathrm{~nm}$ was used insted of $480 \mathrm{~nm}$; CAT and GPx activities was assayed as described elsewhere [6, 7]. Enzymes were extracted with nuclear homogenization in $\mathrm{NaCl}$ solution and centrifugated $60.000 \mathrm{~g}$ for $1 \mathrm{~h}$, supernatants were used. Chromatography of nuclear extracts on hydroxylapatite were carried out as described elsewhere [8], $80 \mathrm{mM}$ sodium phosphate buffer, pH 8.0 was used. HPLC chromatography were carried out on «Pharmacia» (Austria) columns and «ISCO» (USA) HPLC system. Chromatography on Superose $1210 / 30$ was carried out at flow rate $1 \mathrm{ml} / \mathrm{min}$, $0.1 \mathrm{M} \mathrm{NaCl}, 10 \mathrm{mM}$ Tris- $\mathrm{HCl}, \mathrm{pH} 7.6 ; 0.25 \mathrm{ml}$ fractions were collected. The

(C) A. F. PROTAS, 1990 
$K_{\mathrm{ay}}$ coefficients were used for enzymes molecular weight calculations. Chromatography on Mono P 5/20 was carried out at flow rate $1 \mathrm{ml} / \mathrm{min}$, start buffer $25 \mathrm{mM}$ bis-Tris $\mathrm{HCl}, \mathrm{pH} 7.0$, eluent 10:1 polybuffer 74, $\mathrm{pH} 4.0$, fractions were collected in $0.2 \mathrm{pH}$ units. Nuclear chromatin was fractionated with DNAse I digestion as described elsewhere $[8]$ for $10 \mathrm{~min}, 37^{\circ} \mathrm{C}, 30$ units of DNAse I per $1 \mathrm{mg}$ DNA of chromatin. Three fractions were obtained: S1 - the first supernatant after reaction termination and nuclei sedimentation, S2 - the second one after previous sediment extraction with $1 \mathrm{mM}$ EDTA, $1 \mathrm{mM}$ Tris- $\mathrm{HCl}, \mathrm{pH} 7.4$ and the sediment $\mathrm{P}$. Optical analysis were carried out on Beckman DU-65 Spectrophotometer («Beckman», USA).

Results and Discussion Enzymes were released from nuclei under very high ionic strength (Fig. 1): more than $1 \mathrm{M} \mathrm{NaCl}$. Therefore they have strong ionic bounds with DNA. About the same value have only core histones - structural proteins of chromatin [10].

After extraction enzymes were partialy purified with hidroxylapatite chromatography, concentrated with ammonium sulfate precipitation $(45-70 \%$ saturation) and applied on Superose 12 column (Fig. 2). Only one peak was observed for both enzymes. It means that enzymes are not subunitical, or under the operating conditions they completely dissociate to monomers. The $\mathrm{M}_{r}$ of enzymes are: $10 \mathrm{kDa}$ (SOD) and $44 \mathrm{kDa}$ (CAT and GPx).

After gel-filtration the peaks with SOD, CAT and GPx activities were pooled, desalted and applied on Mono $\mathrm{P}$ column. SOD was eluted under $\mathrm{pH}$ 6.0; $\mathrm{CAT}$ and GPx were eluted together (as and under gel-filtration) under $\mathrm{pH} 5.8$ (Fig. 3).
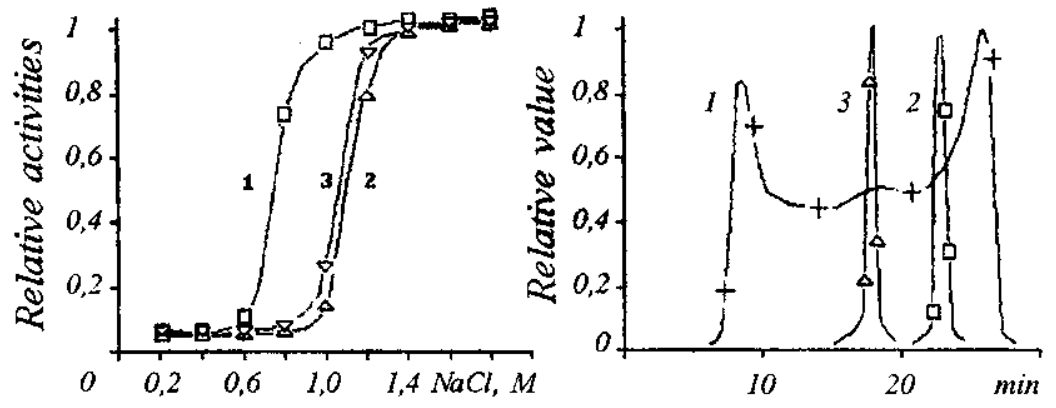

Fig. 1. The extraction curve of SOD (1), CAT (2) and GPx (3) from nuclei

Fig. 2. Chromatography on Superose 12 column: $I$ - absorbance at $280 \mathrm{mn} ; 2$ - activity of SOD; 3 - activity of CAT and GPx
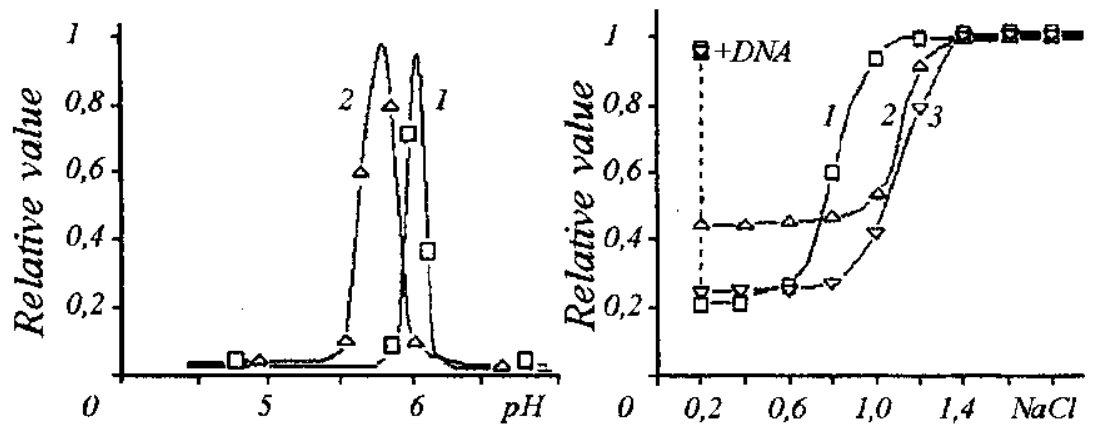

Fig. 3. Chromatofocusing on Mono P column: $1-$ activity of SOD; 2 - activity of CAT and GPx Fig. 4. The effect of ionic strength and DNA $(0.05 \mathrm{mg} / \mathrm{ml})$ on SOD $(l)$ and CAT (2) and GPx (3) activities 
The data about the ionic strength effect on enzymes structure and properties have great significance for proteins which are associated with DNA. These types of analysis allow to model and study protein-DNA interaction. Activities of the SOD and CAT depend on $\mathrm{NaCl}$ concentration (Fig. 4). The data suggest that enzymes exist in two structural forms with low and high activity and have well-marked transitions. It is necessary to note that the positions of these transitions are coincided with extraction curves (Fig. 1). The activities of purified enzymes can be increased not only with ionic strength, but with DNA addition under a physiological $\mathrm{NaCl}$ concentration (dotted line on Fig. 4). So, the interaction with DNA induces the some changes in enzymes molecule structure as $\mathrm{NaCl}$.

With aim to study the enzymes arrangement within chromatin nuclei was fractionated with DNAse I. As well-known, the most sensitive chromatin fraction (it is S1 of present work) consists of transcriptionaly active nucleosomes [11]. Just this fraction is inreached with SOD and CAT (Table).

The enzymes activities in chromatin fractions (ratio activity:DNA, in \%)

\begin{tabular}{c|c|c|c|c}
\hline \multirow{2}{*}{ Fraction } & \multirow{2}{*}{ DNA, \% } & \multicolumn{3}{c}{ Ratio } \\
\cline { 3 - 5 } & & SOD & CAT & GPx \\
\cline { 3 - 5 } S1 & 4.5 & 9.1 & 10.2 & 9.4 \\
S2 & 36.7 & 1.4 & 1.9 & 1.6 \\
P & 59.1 & 0.12 & 0.22 & 0.18 \\
\hline
\end{tabular}

$\mathrm{Cu}, \mathrm{ZnSOD}$ is inhibited with $\mathrm{KCN}$, but not MnSOD. These properties are used always with aim to determ two types of SOD. It was founded that even $10 \mathrm{mM} \mathrm{KCN}$ had no effect on purified nuclear SOD. On the other hand, even $10 \mathrm{mM} \mathrm{CuSO}{ }_{4}$ and/or $\mathrm{ZnSO}_{4}$ did not change SOD activity, but $0,5 \mu \mathrm{M} \mathrm{MnCl}_{2}$ induced about 50-multiple increasing of SOD activity.

So, nuclei contain own MnSOD, CAT and GPx. The main feature of these enzymes is their association with chromatin. On the other hand it does not means that enzymes have many basic residues. The detailed analysis of histone-DNA interactions [12] had shown that for histone octamer the strong ionic association with DNA phosphates about 10-14 arginine residues (no more then two residues per one histone molecule) are enough. So, the enzymes interaction with DNA can provide several (up to five) basic amino acids, but with high specific orientation in frames of the tertiary structure. All the other properties are other, but not very different from cytosolic forms.

It is necessary to note, that under the all conditions CAT and GPx were eluted together. They have about the same properties as well. It allow to suppos that it is one enzyme with the both activities.

A. Ф. Пpomac

Ядерные формы супероксиддисмутазы, каталазы и пероксидазы

Резюме

Ядра клеток коры головного мозга крыс содержат собственные специфические формы супероксиддисмутазы (СОД), каталазы (КАТ) и глутатионпероксидазы (ГПер). Ферменты прочно ассоциированы с хроматином (преимущественно с транскрипционно активной

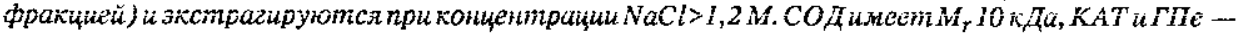


PROTAS A. F.

44 кДа ( гель-фильтрачия); изоэлектрическая точхадля СОД зафиксирована при рН 6, 0, для КАТ и ГПер-5,8 (хроматофокусирование). Актияность ферментов зависит от ионной силь и максимальна при концентрации $\mathrm{NaCl}>1,1 \mathrm{M}$. Ядерная СОД не ингибируется кCN и, видимо, представляет собой $\mathrm{MnCOД.}$

\section{O. Ф. IIpomac}

Ядерні форми супероксиддисмутази, калатази і пероксидази

Резюме

Ядра клітин кори головного мозку иурів містять аласні специфіині форми супероксиддисмутази (СОД), калатази (КАТ) і глутатіонпероксидази (ГПер). Ферменти міцно асоційовані з хроматином (переважно 3 транскрипційно активною фракцією) та ехстрагуються при концентрації $\mathrm{NaCl}>1,2 \mathrm{M}$. СОД має $\mathrm{M}_{r} 10$ кДа, КАT і ГПер- 44 кДа (zель-фільтрація); ізоелектричну точку зафіксовано для СОД при рН 6,0, для КАТ і ГПер - при рН 5,8 (хроматофокусування). Активність ферментів залежить від іонної сили і стає махсимальною

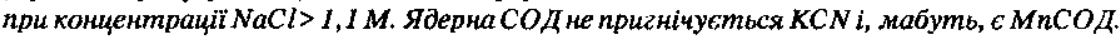

\section{REFERENCES}

1. Armstrong $D$. Free radicals in molecular biology, aging and disease.- New York.: Raven press, $1984 .-416 \mathrm{p}$.

2. Вартанян Л. С., Раиба Ю. Э., Наглер Л. Г. Мембраны субклеточных органелл как источник супероксидных радикалов при ишемии // Бюл. эксперим. биологии и медицины. -1990 . - № 6.-C. $550-552$.

3. Maestro Del R., McDonald W. Subcellular localization of superoxide dismutases, glutathione peroxidase and catalase in developing rat cerebral cortex // Mech. Agein and Develop.1989.-48, N 1.-P. 15-31.

4. Mazeaud F., Michelson A. M. Distribution of superoxide dismutase and glutathione peroxidase in carp: erythrocyte manganese SOD // Biochem, and Biophys. Res. Communs. - 1979.-86.P. $1161-1165$

5. Misra $H . P$. , Fridovich $i$. The role of superoxide anion in the autooxidation of epinephrine and simple assay for superoxide dismutase // J. Biol. Chem. - 1972. $-247, \mathrm{~N} 10 .-\mathrm{P}$. 3170--3175.

6. Королюк М. А., Иванова Л. И., Майорова И. Г. Метод определения активности каталазы // Лаб. дело.-1988. - № 1.-C. $16-19$.

7. Greenwald R. A. Handbook of methods for oxygen radicalresearch.m Boca Roton: CRC press Inc., $1985 .-340 \mathrm{p}$.

8. Khrapunov S. N., Protas A. F., Dragan A. I., Berdishev G. D. Structure of histone tetramer H3-H4. 1 // Int. J. Biol. Macromol. -1984.-6, N 1.-P. 26-30.

9. Протас А. Ф., Чаяло П. П. Влияние низких доз внешнего гамма-облуцения на структуру хроматина и активность гистон-специфических протеиназ клеток головного мозга крыс // Радиобиология. - 1991.-31, № 6.-C. $733-738$.

10. Ichimura S., Mita K., Zama M. Essentional role of arginine residues in the folding of deoxyribonucleic acid into nucleosome cores // Biochemistry. - 1981,-21, N 21. - P. 53295334.

11. Weisbrod S. T. Active chromatin // Nature.-1982.-297, N 5864.-P. 289-295

12. Ashikawa I., Nishimura Y., Tsobi $M$. et al. Lifetime of tyrosine fluorescence in nucleosome core particles // J. Biochem.-1982.-91, N 6.-P. 2047-2055.

UDC $577.15+576.312$

Received 30.10 .95 